\title{
Author's Corrigendum
}

\section{Hemopoiesis in the Thymus}

\author{
MARION D. KENDALL
}

Thymus Laboratory, The Babraham Institute, Cambridge CB2 4AT, and Pharmacology Department, UMDS, London SE1 7EH, UK

\begin{abstract}
The above paper (Vol. 4. No. 3, pp. 157-168) was published with the omission of a sentence. The omission occurred on the sixth line from the end of page 157. The information in the following paragraph is correct.
\end{abstract}

mouse has two lineages of stem cells. The majority were Thy $1^{10}, \mathrm{Lin}-\mathrm{Sca}-1^{+}$cells, with potent myeloerythroid lineage capabilities as well as being thymus-repopulating cells. However, a small population of similar cells but Sca- also had CFU-S (colony forming units-spleen) capabilities and were probably on the erythroid line of development. Alternatively, truly multi-potential stem cells of the embryo might remain in the thymus in adult life, and on occasion be "awakened". Indeed, variations on the extent to which this might happen could be the key to many of the observations quoted in this review. 


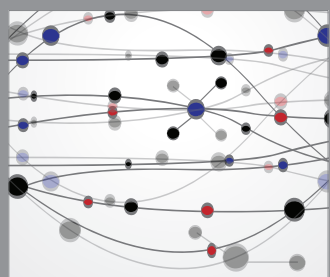

The Scientific World Journal
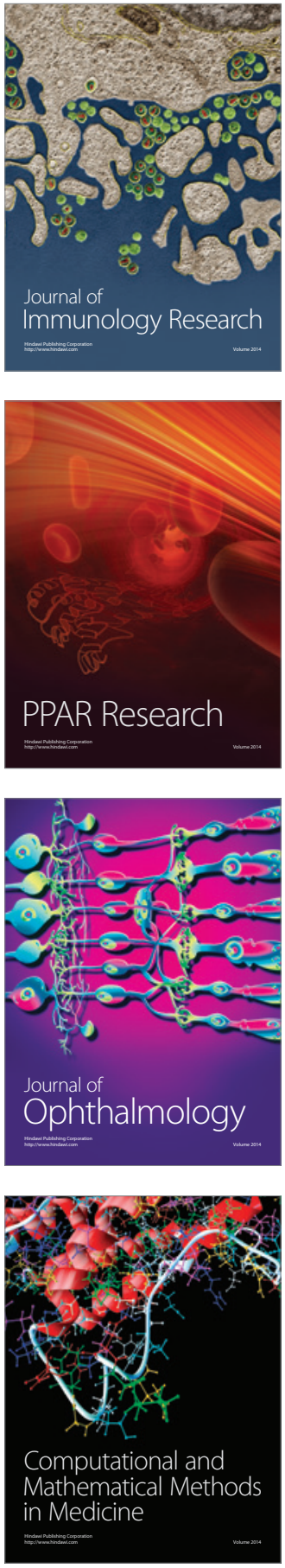

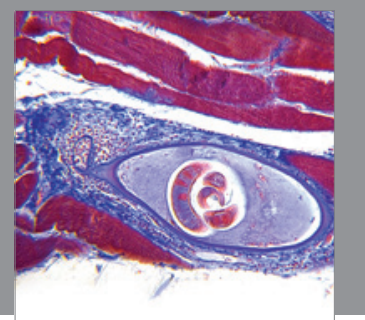

Gastroenterology

Research and Practice
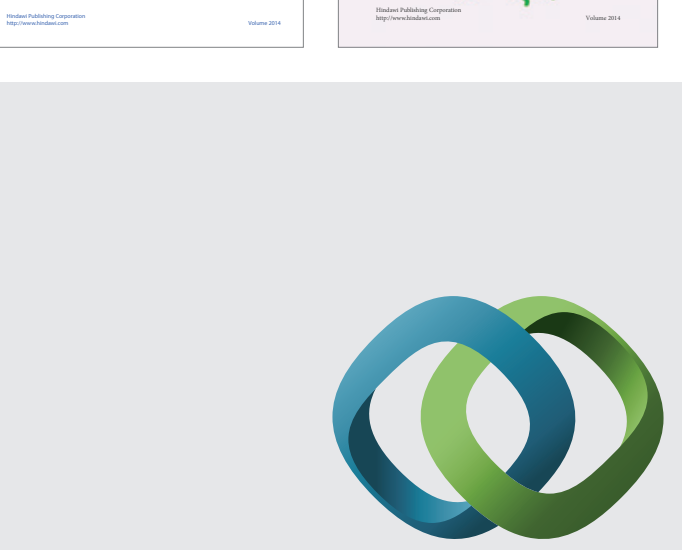

\section{Hindawi}

Submit your manuscripts at

http://www.hindawi.com
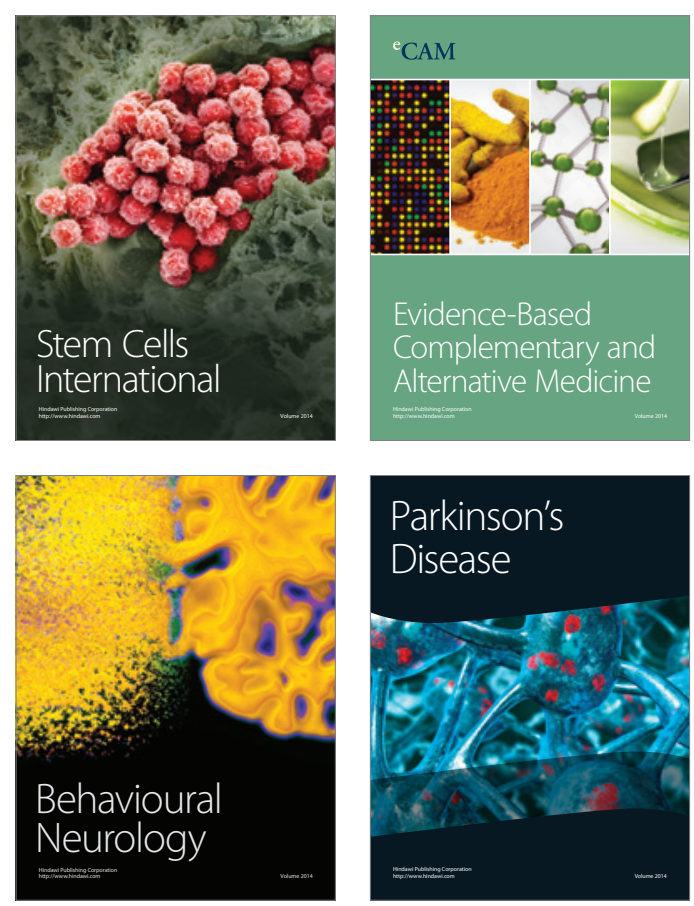

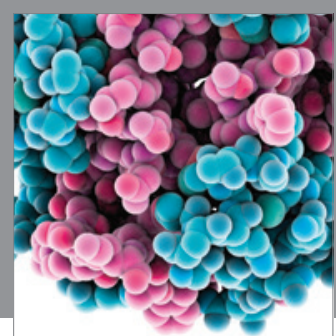

Journal of
Diabetes Research

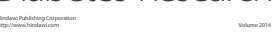

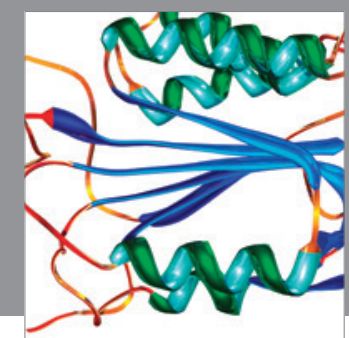

Disease Markers
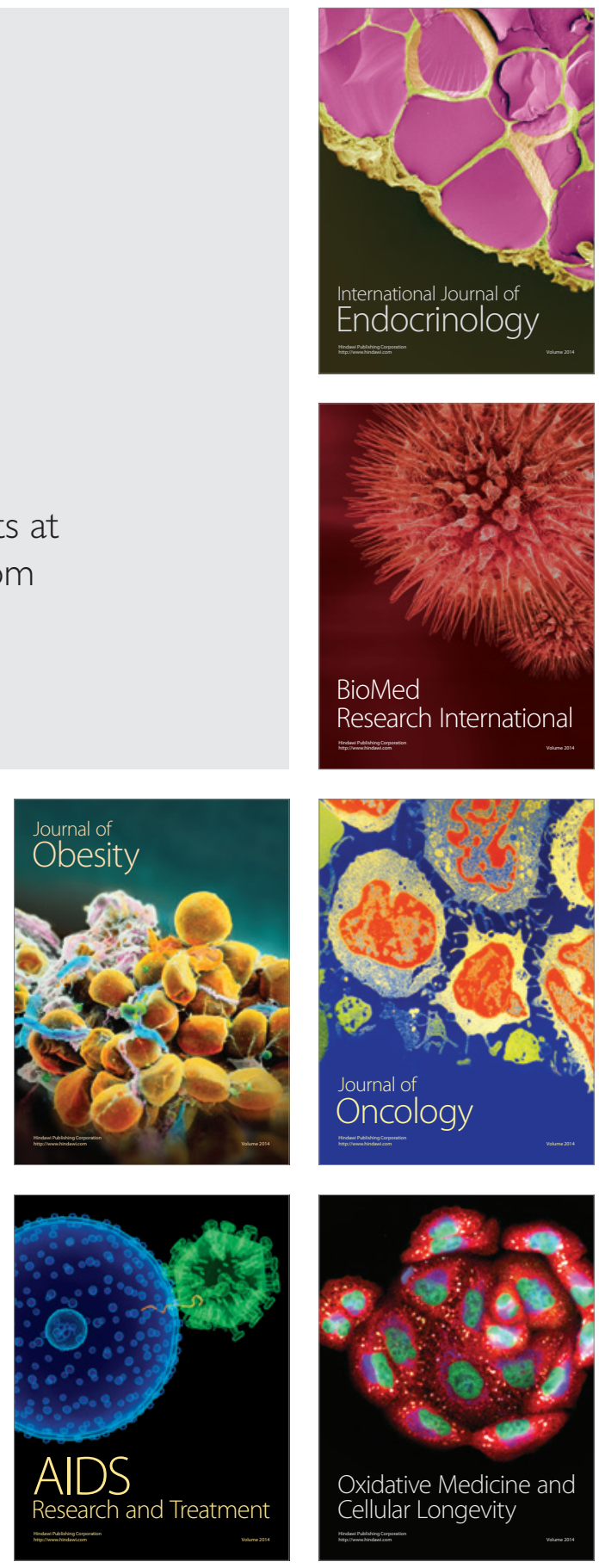